\title{
Luteimonas terricola sp. nov., a psychrophilic bacterium isolated from soil
}

\author{
De-Chao Zhang, ${ }^{1}$ Hong-Can Liu, ${ }^{2}$ Yu-Hua Xin, ${ }^{2}$ Yu-Guang Zhou, ${ }^{2}$ \\ Franz Schinner ${ }^{1}$ and Rosa Margesin ${ }^{1}$
}

Correspondence

Rosa Margesin

Rosa.Margesin@uibk.ac.at

\author{
${ }^{1}$ Institute of Microbiology, University of Innsbruck, Technikerstrasse 25, A-6020 Innsbruck, Austria \\ ${ }^{2}$ China General Microbiological Culture Collection Center and State Key Laboratory of Microbial \\ Resources, Institute of Microbiology, Chinese Academy of Sciences, Beijing 100101, PR China
}

Strain BZ92 $\mathrm{r}^{\top}$ was isolated from hydrocarbon-contaminated soil. Cells were Gram-negative, aerobic, rod-shaped and cold-adapted (growth at $1-25^{\circ} \mathrm{C}$ ). The major fatty acids were iso$\mathrm{C}_{15: 0}(25.6 \%)$, iso- $\mathrm{C}_{17: 1} \omega 9 c(24.9 \%)$, iso- $\mathrm{C}_{11: 0}(18.4 \%)$ and iso- $\mathrm{C}_{11: 0} 3-\mathrm{OH}(16.2 \%)$. The predominant ubiquinone was ubiquinone-8. The genomic DNA G+C content was 72.0 mol\%. Phylogenetic analysis based on $16 \mathrm{~S}$ rRNA gene sequences indicated that strain $B Z 92 r^{\top}$ was a member of the genus Luteimonas (94.5-95.2\% 16S rRNA gene sequence similarity). On the basis of phenotypic, chemotaxonomic and phylogenetic distinctiveness, strain BZ92 ${ }^{\top}$ was considered to represent a novel species of the genus Luteimonas. The name Luteimonas terricola sp. nov. is proposed, with BZ92 $r^{\top}\left(=\mathrm{DSM} 22344^{\top}=\right.$ CGMCC $\left.1.8985^{\top}\right)$ as the type strain.
The genus Luteimonas was first proposed by Finkmann et al. (2000) to accommodate bacteria that are aerobic, Gram-negative rods that contain ubiquinone- 8 as the major ubiquinone and iso- $\mathrm{C}_{15: 0}$ as the major fatty acid. Currently, the genus Luteimonas includes four species: Luteimonas mephitis (Finkmann et al., 2000), L. composti (Young et al., 2007), L. aquatica (Chou et al., 2008) and L. marina (Baik et al., 2008). The type strains of these species were respectively isolated from ammonia-supplied biofilters in Germany, compost generated from food waste in Taiwan, fresh water from southern Taiwan and seawater from Korea. They are all mesophilic. In this study, we report on the characterization of a novel bacterium, strain $B Z 92 \mathrm{r}^{\mathrm{T}}$, of the genus Luteimonas. The strain was isolated from soil from an industrial site contaminated with hydrocarbons and is the first psychrophilic representative of the genus Luteimonas, i.e. it is well adapted to low temperatures (Margesin et al., 2008) and able to grow at temperatures as low as $1^{\circ} \mathrm{C}$. We use the term 'psychrophile' as a general term that describes a micro-organism that grows in a cold environment. The use of growth rates to define the optimum growth temperature, as described by Morita (1975), has been shown to be ambiguous and inappropriate (Feller \& Gerday, 2003; Cavicchioli, 2006).

Strain BZ92 $\mathrm{r}^{\mathrm{T}}$ was isolated from soil from an industrial site contaminated with large amounts of heavy oil, located in Bozen, South Tyrol, Italy. The soil was collected under sterile conditions in spring 2008. A soil sample (10 g) was shaken with $90 \mathrm{ml}$ sterile $1 \%$ sodium pyrophosphate

The GenBank/EMBL/DDBJ accession number for the 16S rRNA gene sequence of strain BZ92 $r^{\top}$ is FJ948107.
(pH 8.5) for $20 \mathrm{~min}$ at 150 r.p.m. Appropriate dilutions, prepared with sterile $0.9 \% \mathrm{NaCl}$, were plated $(0.1 \mathrm{ml})$ on a low-strength medium, R2A agar $(0.05 \%$ yeast extract, $0.05 \%$ peptone, $0.05 \%$ Casamino acids, $0.05 \%$ glucose, $0.05 \%$ starch, $0.03 \%$ sodium pyruvate, $0.03 \% \mathrm{~K}_{2} \mathrm{HPO}_{4}$, $0.005 \% \mathrm{MgSO}_{4}, 1.5 \%$ agar; $\mathrm{pH} 7$ ), and incubated at $20{ }^{\circ} \mathrm{C}$. One of the pure cultures subsequently obtained was yellow pigmented and was designated BZ92 $\mathrm{r}^{\mathrm{T}}$. Strain $\mathrm{BZ} 92 \mathrm{r}^{\mathrm{T}}$ was routinely cultivated in $\mathrm{R} 2 \mathrm{~A}$ medium at $20{ }^{\circ} \mathrm{C}$. For use as a reference strain, L. mephitis DSM $12574^{\mathrm{T}}$ was routinely grown on nutrient agar $(0.5 \%$ peptone, $0.3 \%$ meat extract, $1.5 \%$ agar; $\mathrm{pH} 7)$ at $30{ }^{\circ} \mathrm{C}$.

DNA was extracted and purified as described by Sambrook et al. (1989). The gene encoding 16S rRNA was amplified by PCR with two universal primers (Zhang et al., 2006). PCR products were cloned into pGEM-T vectors using the pGEM-T easy vector system (Promega), according to the manufacturer's instructions. Sequencing reactions were carried out using ABI Big Dye 3.1 sequencing kit and an automated DNA sequencer (ABI 3730; Applied BioSystems). The nearly complete (1537 nt) 16S rRNA gene sequence of strain BZ92 $\mathrm{r}^{\mathrm{T}}$ was submitted to GenBank and EMBL to search for similar sequences using the BLAST algorithm. A phylogenetic tree was constructed using Kimura's twoparameter and pairwise-deletion model analysis implemented in the program MEGA version 3.0 (Kumar et al., 2004). The resultant tree topologies were evaluated by bootstrap analysis based on 1000 replicates. The phylogenetic analysis (Fig. 1) showed that strain BZ92 $\mathrm{r}^{\mathrm{T}}$ was grouped with members of the genus Luteimonas and formed a distinct cluster with L. mephitis B1953/27.1 ${ }^{\mathrm{T}}$ (16S rRNA gene sequence similarity $94.9 \%$ ). Similar tree topologies were 


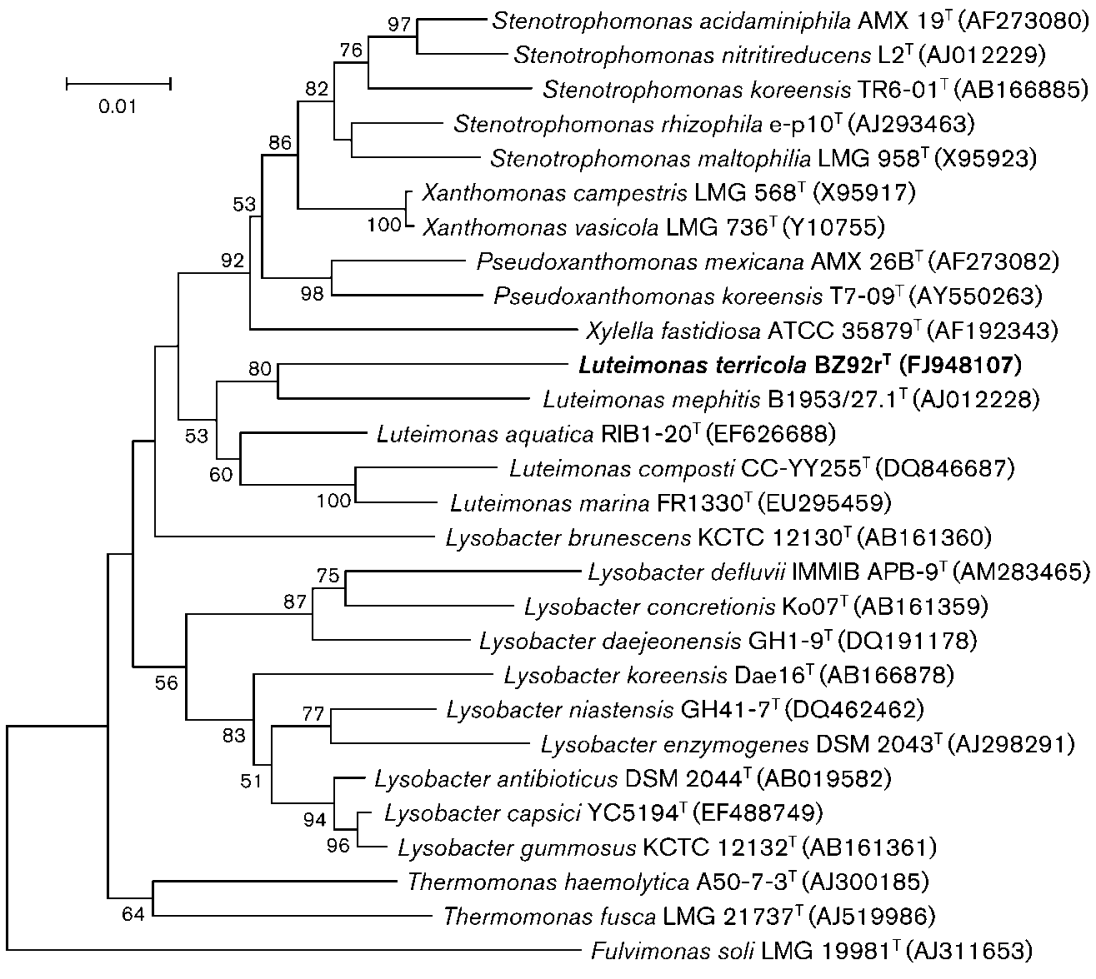

Fig. 1. Neighbour-joining tree, based on $16 \mathrm{~S}$ rRNA gene sequence data, showing the phylogenetic position of strain $B Z 92 r^{\top}$, recognized members of the genus Luteimonas and representatives of some related taxa. Percentages at nodes are levels of bootstrap support based on 1000 replications. Bar, $1 \%$ sequence divergence. found in the tree generated with the maximum-parsimony algorithm (data not shown). Lower similarity values $(<97.0 \%)$ were found with the type strains of other Luteimonas species. It has been suggested that levels of DNA-DNA relatedness less than $70 \%$ are observed between strains with less than $97 \%$ 16S rRNA gene sequence similarity (Stackebrandt \& Goebel, 1994). Therefore, strain $\mathrm{BZ92} \mathrm{r}^{\mathrm{T}}$ is genotypically distinct from other recognized species of the genus Luteimonas.

The cell morphology was examined by phase-contrast microscopy $(\times 1000)$. The Gram reaction was determined by Gram staining and confirmed by the $\mathrm{KOH}$ lysis test. API tests (API 20E, API 20NE, API ZYM; bioMérieux) were performed at $20{ }^{\circ} \mathrm{C}$ to determine physiological and biochemical characteristics, according to the manufacturer's instructions, and the API M system was used to evaluate cell motility. Sensitivity to antibiotics was determined on R2A agar supplemented with various antibiotics at $20{ }^{\circ} \mathrm{C}$. The morphological, physiological and biochemical characteristics of strain BZ92 $\mathrm{r}^{\mathrm{T}}$ are given in the species description and Table 1.

Respiratory quinones were extracted and purified according to Collins (1985) and were analysed by HPLC (Wu et al., 1989), using ubiquinone-8 from L. mephitis DSM $12574^{\mathrm{T}}$ as a reference. Strain $\mathrm{BZ}{ }^{\mathrm{T}} \mathrm{r}^{\mathrm{T}}$ contained ubiquinone- 8 as the major quinone. For fatty acid methyl ester analysis, cell biomass of strain BZ92 $\mathrm{r}^{\mathrm{T}}$ was harvested from tryptic soy agar (TSA) plates after incubation at $20{ }^{\circ} \mathrm{C}$ for 2 days. The fatty acid methyl esters were extracted and prepared according to the standard protocol of the Microbial Identification system (Sasser, 1990). The major fatty acids were iso- $\mathrm{C}_{15: 0}(25.6 \%)$, iso- $\mathrm{C}_{17: 1} \omega 9 c(24.9 \%)$, iso- $\mathrm{C}_{11: 0}(18.4 \%)$ and iso- $\mathrm{C}_{11: 0} 3-\mathrm{OH}(16.2 \%)$. The fatty acid profile of strain $\mathrm{BZ} 92 \mathrm{r}^{\mathrm{T}}$ differs from those of other Luteimonas species by having larger proportions of iso$\mathrm{C}_{11: 0}$ and iso- $\mathrm{C}_{11: 0}$ 3-OH (Finkmann et al., 2000; Young et al., 2007; Baik et al., 2008; Chou et al., 2008). The fatty acid profiles of strain $B Z 92 \mathrm{r}^{\mathrm{T}}$ and the type strains of Luteimonas species are shown in Table 2.

The $\mathrm{G}+\mathrm{C}$ content of the DNA was tested by the thermal denaturation method (Sly et al., 1986) with DNA from Escherichia coli $\mathrm{K}-12$ as the reference, using a model Lambda $35 \mathrm{UV} / \mathrm{Vis}$ spectrometer equipped with a temperature program controller (PerkinElmer). The DNA G $+\mathrm{C}$ content of strain $\mathrm{BZ} 92 \mathrm{r}^{\mathrm{T}}$ was $72.0 \mathrm{~mol} \%$.

Strain $B Z 92 r^{\mathrm{T}}$ differs from the type strains of the other species of the genus Luteimonas mainly by its psychrophilic growth characteristics: i.e. the strain is able to grow at low temperatures (down to $1{ }^{\circ} \mathrm{C}$ ), while no growth occurs at $30{ }^{\circ} \mathrm{C}$, which has not yet been described for other Luteimonas species. According to its physiological and phylogenetic properties, the strain is closely related to $L$. mephitis, the type species of the genus. Based on the phenotypic, phylogenetic and genomic evidence, strain BZ92 $r^{\mathrm{T}}$ was identified as a representative of a novel species of Luteimonas, for which the name Luteimonas terricola sp. nov. is proposed.

\section{Description of Luteimonas terricola sp. nov.}

Luteimonas terricola (ter.ri'co.la. L. n. terra earth, soil; L. suff. - cola inhabitant, dweller; N.L. n. terricola a dweller 
Table 1. Phenotypic characteristics that differentiate strain $B Z 92 r^{\top}$ from the type strains of Luteimonas species

Strains: 1, Luteimonas terricola sp. nov. BZ92 ${ }^{\mathrm{T}} ; 2$, L. aquatica $\mathrm{LMG}$ $24212^{\mathrm{T}}$ (data from Chou et al., 2008); 3, L. composti CC-YY255 ${ }^{\mathrm{T}}$ (Young et al., 2007); 4, L. marina JCM $12488^{\mathrm{T}}$ (Baik et al., 2008); 5, L. mephitis DSM $12574^{\mathrm{T}}$ (Finkmann et al., 2000; Chou et al., 2008). All strains were positive for aerobic growth and catalase, oxidase, alkaline and acid phosphatases, esterase (C4), esterase lipase (C8), leucine arylamidase and naphthol-AS-BI-phosphohydrolase activities. All strains were negative for the Gram reaction, spore formation, motility, glucose fermentation, production of indole and urease, lipase (C14), arginine dihydrolase, lysine dihydrolase, ornithine dihydrolase, $\alpha$-fucosidase, $\alpha$-galactosidase and $\beta$-glucuronidase activities and adipate, caprate and phenylacetate assimilation. + , Positive; $w$, weak; - , negative; ND, no data available.

\begin{tabular}{|c|c|c|c|c|c|}
\hline Characteristic & 1 & 2 & 3 & 4 & 5 \\
\hline $\begin{array}{l}\text { Temperature range for } \\
\text { growth }\left({ }^{\circ} \mathrm{C}\right)\end{array}$ & $1-25$ & $15-37$ & $20-45$ & $20-42$ & $T_{\max } 37$ \\
\hline Nitrate reduction & + & - & + & - & - \\
\hline \multicolumn{6}{|l|}{ Hydrolysis of: } \\
\hline Aesculin & - & ND & + & + & - \\
\hline Gelatin & - & $\mathrm{ND}$ & + & + & + \\
\hline \multicolumn{6}{|l|}{ Enzyme assays (API ZYM) } \\
\hline$\alpha$-Chymotrypsin & $\mathrm{W}$ & - & + & + & - \\
\hline $\begin{array}{l}N \text {-Acetyl- } \beta \text { - } \\
\text { glucosaminidase }\end{array}$ & - & + & + & + & - \\
\hline$\alpha$-Mannosidase & - & - & - & + & - \\
\hline Cystine arylamidase & - & + & - & - & - \\
\hline Valine arylamidase & - & + & + & + & + \\
\hline \multicolumn{6}{|l|}{ Assimilation of: } \\
\hline Arabinose & - & - & + & + & - \\
\hline Citrate & - & - & - & + & - \\
\hline Malate & - & + & - & + & - \\
\hline D-Glucose & - & + & + & + & - \\
\hline Maltose & - & + & + & + & - \\
\hline D-Mannose & - & + & - & - & - \\
\hline Tween 80 & - & + & - & $\mathrm{w}$ & + \\
\hline DNA G $+\mathrm{C}$ content $(\mathrm{mol} \%)$ & 72.0 & 70.3 & 68.1 & 67.6 & 67.0 \\
\hline
\end{tabular}

upon earth, soil-dweller, referring to the isolation of the type strain from soil).

Cells are aerobic, Gram-negative, non-spore-forming, nonmotile and rod-shaped $(0.6-0.8 \times 1.8-2.2 \mu \mathrm{m}$ in $\mathrm{R} 2 \mathrm{~A}$ medium). Colonies on R2A agar are light yellow, round, convex, opaque and smooth with entire margins, approx. $1-1.5 \mathrm{~mm}$ in diameter. Growth occurs in R2A medium at $1-25{ }^{\circ} \mathrm{C}$, with the highest cell yields at $10-15{ }^{\circ} \mathrm{C}$ and the fastest growth at $25{ }^{\circ} \mathrm{C}$; growth on $\mathrm{R} 2 \mathrm{~A}$ agar at $1{ }^{\circ} \mathrm{C}$ is very weak. Growth on R2A agar occurs at $\mathrm{pH} 7-8$ and with 0 $3 \%(\mathrm{w} / \mathrm{v}) \mathrm{NaCl}$. Produces catalase and cytochrome oxidase but not indole, $\mathrm{H}_{2} \mathrm{~S}$ or urease. Reduces nitrate. Does not hydrolyse aesculin or gelatin. Positive for alkaline phosphatase, leucine arylamidase and naphthol-AS-BI-phosphohydrolase, weakly positive for esterase (C4), esterase lipase (C8), acid phosphatase, trypsin and $\alpha$-chymotrypsin, but negative for lipase (C14), cystine arylamidase, arginine
Table 2. Comparison of cellular fatty acid compositions of strain $\mathrm{BZ} 2 \mathrm{r}^{\top}$ and the type strains of Luteimonas species

Strains: 1, L. terricola sp. nov. BZ92 $\mathrm{r}^{\mathrm{T}} ; 2$, L. aquatica LMG $24212^{\mathrm{T}}$ (data from Chou et al., 2008); 3, L. composti CC-YY255 ${ }^{\mathrm{T}}$ (Young et al., 2007); 4, L. marina JCM $12488^{\mathrm{T}}$ (Baik et al., 2008); 5, L. mephitis DSM $12574^{\mathrm{T}}$ (Young et al., 2007). Values are percentages of total fatty acids.

\begin{tabular}{|c|c|c|c|c|c|}
\hline Fatty acid & 1 & 2 & 3 & 4 & 5 \\
\hline \multicolumn{6}{|c|}{ Straight-chain saturated } \\
\hline $\mathrm{C}_{14: 0}$ & 0.5 & 0.2 & - & 0.7 & 0.7 \\
\hline $\mathrm{C}_{16: 0}$ & 0.9 & 2.4 & 4.7 & 5.9 & 1.6 \\
\hline \multicolumn{6}{|l|}{ Branched saturated } \\
\hline iso- $\mathrm{C}_{10: 0}$ & 0.1 & - & 0.4 & - & 0.1 \\
\hline iso- $\mathrm{C}_{11: 0}$ & 18.4 & 4.0 & 6.5 & 6.4 & 5.2 \\
\hline anteiso- $\mathrm{C}_{11: 0}$ & 0.1 & - & 0.3 & 0.2 & 0.2 \\
\hline iso- $\mathrm{C}_{13: 0}$ & 0.4 & 0.2 & - & 0.1 & 0.5 \\
\hline iso- $\mathrm{C}_{14: 0}$ & 0.3 & 0.3 & 1.9 & 0.2 & 1.5 \\
\hline iso- $\mathrm{C}_{15: 0}$ & 25.6 & 25.3 & 25.5 & 26.2 & 47.4 \\
\hline anteiso- $\mathrm{C}_{15: 0}$ & 0.7 & 6.2 & 2.7 & 4.5 & 3.0 \\
\hline iso- $\mathrm{C}_{16: 0}$ & 0.8 & 4.4 & 13.8 & 1.7 & 5.6 \\
\hline iso- $\mathrm{C}_{17: 0}$ & 3.9 & 21.5 & 5.5 & 14.5 & 5.5 \\
\hline \multicolumn{6}{|l|}{ Unsaturated } \\
\hline iso- $\mathrm{C}_{15: 1}$ & 3.6 & - & 1.9 & - & 3.0 \\
\hline iso- $\mathrm{C}_{17: 1} \omega 9 c$ & 24.9 & 22.3 & 25.5 & 26.0 & 18.7 \\
\hline \multicolumn{6}{|l|}{ Hydroxy } \\
\hline iso- $\mathrm{C}_{11: 0} 3-\mathrm{OH}$ & 16.2 & 6.7 & 5.5 & 4.7 & 5.3 \\
\hline Summed feature $3^{*}$ & 2.6 & 1.4 & 5.5 & 2.2 & 0.9 \\
\hline
\end{tabular}

* Summed features represent two or three fatty acids that cannot be separated by the Microbial Identification System. Summed feature 3 consisted of $\mathrm{C}_{16: 1} \omega 7 c$ and/or iso- $\mathrm{C}_{15: 0} 2-\mathrm{OH}$.

dihydrolase, lysine dihydrolase, ornithine dihydrolase, tryptophan deaminase, valine arylamidase, $\alpha$-fucosidase, $\alpha$-galactosidase, $\beta$-glucuronidase, $\alpha$-glucosidase, $\beta$-glucosidase, $\quad N$-acetyl- $\beta$-glucosaminidase and $\alpha$-mannosidase. Does not utilize L-arabinose, D-glucose, maltose, Dmannitol, D-mannose, $N$-acetylglucosamine, gluconate, citrate, adipic acid, capric acid, malic acid or phenylacetic acid as carbon sources. Does not ferment glucose or other carbon sources in the API $50 \mathrm{CH}$ B/E system. Resistant to ampicillin and penicillin $\mathrm{G}$, but sensitive to chloramphenicol, kanamycin, rifampicin, streptomycin and tetracycline (all at $30 \mu \mathrm{g} \mathrm{ml}^{-1}$ ). Ubiquinone-8 is the major ubiquinone. The predominant cellular fatty acids are iso- $\mathrm{C}_{15: 0}$, iso$\mathrm{C}_{17: 1} \omega 9 c$, iso- $\mathrm{C}_{11: 0}$ and iso- $\mathrm{C}_{11: 0} 3-\mathrm{OH}$. The DNA G+C content of the type strain is $72.0 \mathrm{~mol} \%$.

The type strain is $\mathrm{BZ} 2 \mathrm{r}^{\mathrm{T}}\left(=\mathrm{DSM} 22344^{\mathrm{T}}=\right.$ CGMCC $1.8985^{\mathrm{T}}$ ), isolated from hydrocarbon-contaminated soil in Bozen, South Tyrol, Italy.

\section{Acknowledgements}

This research work was supported by a grant from the Autonome Provinz Bozen, Südtirol. We thank P. Thurnbichler for technical assistance. 


\section{References}

Baik, K. S., Park, S. C., Kim, M. S., Kim, E. M., Park, C., Chun, J. \& Seong, C. N. (2008). Luteimonas marina sp. nov., isolated from seawater. Int J Syst Evol Microbiol 58, 2904-2908.

Cavicchioli, R. (2006). Cold-adapted archaea. Nat Rev Microbiol 4, 331-343.

Chou, J.-H., Cho, N.-T., Arun, A. B., Young, C.-C. \& Chen, W.-M. (2008). Luteimonas aquatica sp. nov., isolated from fresh water from Southern Taiwan. Int J Syst Evol Microbiol 58, 2051-2055.

Collins, M. D. (1985). Isoprenoid quinone analysis in classification and identification. In Chemical Methods in Bacterial Systematics, pp. 267-287. Edited by M. Goodfellow \& D. E. Minnikin. London: Academic Press.

Feller, G. \& Gerday, C. (2003). Psychrophilic enzymes: hot topics in cold adaptation. Nat Rev Microbiol 1, 200-208.

Finkmann, W., Altendorf, K., Stackebrandt, E. \& Lipski, A. (2000). Characterization of $\mathrm{N}_{2} \mathrm{O}$-producing Xanthomonas-like isolates from biofilters as Stenotrophomonas nitritireducens sp. nov., Luteimonas mephitis gen. nov., sp. nov. and Pseudoxanthomonas broegbernensis gen. nov., sp. nov. Int J Syst Evol Microbiol 50, 273-282.

Kumar, S., Tamura, K. \& Nei, M. (2004). MEGA3: integrated software for molecular evolutionary genetics analysis and sequence alignment. Brief Bioinform 5, 150-163.

Margesin, R., Schinner, F., Marx, J.-C. \& Gerday, C. (editors) (2008). Psychrophiles: From Biodiversity to Biotechnology. Berlin \& Heidelberg: Springer.
Morita, R. Y. (1975). Psychrophilic bacteria. Bacteriol Rev 39, 133167.

Sambrook, J., Frisch, E. F. \& Maniatis, T. (1989). Molecular Cloning: a Laboratory Manual, 2nd edn. Cold Spring Harbor, NY: Cold Spring Harbor Laboratory.

Sasser, M. (1990). Identification of bacteria by gas chromatography of cellular fatty acids, Technical Note 101. Newark, DE: MIDI Inc.

Sly, L. I., Blackall, L. L., Kraat, P. C., Tian-Shen, T. \& Sangkhobol, V. (1986). The use of second derivative plots for the determination of mol\% guanine plus cytosine of DNA by the thermal denaturation method. J Microbiol Methods 5, 139-156.

Stackebrandt, E. \& Goebel, B. M. (1994). Taxonomic note: a place for DNA-DNA reassociation and 16S rRNA sequence analysis in the present species definition in bacteriology. Int J Syst Bacteriol 44, 846849.

Wu, C., Lu, X., Qin, M., Wang, Y. \& Ruan, J. (1989). Analysis of menaquinone compound in microbial cells by HPLC. Microbiology [English translation of Microbiology (Beijing)] 16, 176-178.

Young, C.-C., Kämpfer, P., Chen, W.-M., Yen, W.-S., Arun, A. B., Lai, W.-A., Shen, F.-T., Rekha, P. D., Lin, K.-Y. \& Chou, J.-H. (2007). Luteimonas composti sp. nov., a moderately thermophilic bacterium isolated from food waste. Int J Syst Evol Microbiol 57, 741744.

Zhang, D.-C., Wang, H.-X., Liu, H.-C., Dong, X.-Z. \& Zhou, P.-J. (2006). Flavobacterium glaciei sp. nov., a novel psychrophilic bacterium isolated from the China No.1 glacier. Int J Syst Evol Microbiol 56, 2921-2925. 